\title{
ROZDZIA 6
}

\author{
Krzysztof Sakowski*
}

\section{Zajęcia projektowe jako walidacja kompetencji zdobytych w trakcie studiów neofilologicznych drugiego stopnia}

\section{Wprowadzenie}

Istotą kształcenia neofilologicznego na uczelniach wyższych w Polsce są trzy filary rozwoju ujęte $\mathrm{w}$ dokumencie stanowiącym podstawę dla programów kształcenia, sylabusów etc., to jest w opisie kształcenia. Te trzy filary to wiedza, umiejętności oraz kompetencje społeczne i personalne. Zrównoważony rozwój we wszystkich wymienionych zakresach ma zapewniać studentom odpowiednie przygotowanie, zarówno teoretyczne, jak i praktyczne, umożliwiające udane rozpoczęcie kariery zawodowej. Tyle można powiedzieć o założeniach teoretycznych. W praktyce jednak okazuje się, że mimo nieustannej pogoni za zmieniającym się krajobrazem gospodarczym oraz społecznym i wynikającymi z tego staraniami ze strony władz Instytutu Filologii Germańskiej oraz Wydziału Filologicznego UŁ, aby dostosować programy kształcenia i ofertę przedmiotów do wymogów rynku pracy i zmieniającego się świata, świadomość własnych kompetencji oraz próba kreatywnego, nieodtwórczego podejścia do posiadanej wiedzy stanowi dla wielu przyszłych adeptów germanistyki drugiego stopnia nie lada wyzwanie. Stało się to szczególnie dobitnie widoczne na prowadzonych przeze mnie zajęciach „projekt translatoryczny lub biznesowy".

*Uniwersytet Łódzki, Instytut Filologii Germańskiej. 
Niniejszy artykuł stawia sobie dlatego za cel retrospektywne przyjrzenie się przebiegowi opisywanych zajęć oraz refleksję nad sensem prowadzenia takich właśnie dydaktycznych projektów. Aby dać miejsce takim przemyśleniom, nieodzowne jest jednak zapoznanie się z warunkami ramowymi i organizacyjnymi, jakie legły u podstaw stworzenia takiego przedmiotu.

\section{Geneza zajęć}

Pamiętając dawną charakterystykę ścieżek zawodowych dla kierunków neofilologicznych, można było właściwie mówić o szerokim udziale ich absolwentów w trzech podstawowych branżach usług, tj. w sektorze edukacyjnym, sektorze tłumaczeniowym i turystycznym. Procentowy udział osób trafiających do wymienionych sektorów odpowiadał przy tym kolejności ich wymieniania. Sytuacja rynkowa zaczęła ulegać diametralnej zmianie około 10-15 lat temu, wraz z pojawieniem się na polskim (i co za tym idzie - również na łódzkim) rynku pracy centrów usług wspólnych (SSC) i podmiotów zewnętrznych zajmujących się wykonywaniem usług biznesowych dla klientów korporacyjnych (BPO). Wskutek tego znacząco wzrosło zapotrzebowanie na pracowników operujących z wysoką biegłością językami europejskimi oraz językiem angielskim rozumianym jako business-pidgin. Doświadczenie firm ww. sektora rekrutujących na swych przyszłych pracowników absolwentów różnych kierunków wskazywało przy tym na przewagę kompetencyjną i komunikacyjną studentów neofilologii. Łatwiej było bowiem przeszkolić do obsługi i rozumienia istoty prostych procesów z zakresu księgowości, logistyki czy też HR osoby dobrze znające wymagany do tego procesu język, niż nauczyć języka osoby posiadające szeroką wiedzę i umiejętności odpowiednie do pracy w tych działach, czyli chociażby absolwentów kierunków ekonomicznych lub tych związanych z marketingiem i zarządzaniem.

Na drugim biegunie zmian należy odnotować stopniowo narastające nasycenie sektora edukacyjnego, tłumaczeniowego i turystycznego przez absolwentów z lat największego boomu edukacyjnego, 1995-2005, co wzmagało problemy ze znalezieniem zatrudnienia w dziedzinach, $w$ których neofilologie kształciły przez ostatnie dziesięciolecia i w dalszym ciągu traktowały ten teren działań edukacyjnych jako domyślny i jednocześnie spójny z prowadzonymi przez siebie badaniami naukowymi.

Ostatnim czynnikiem katalizującym zmiany na uczelniach wyższych w Polsce stała się reforma oświaty z roku 1999, wprowadzająca nowy kształt matury i znosząca egzaminy wstępne. Spowodowała ona dysonans między potrzebami kierunków neofilologicznych w sprawdzaniu zakresu kompetencji 
językowej a formułą egzaminacyjną proponowaną przez CKE ${ }^{1}$. Dysonans ten polegał w dużej mierze na położeniu punktu ciężkości na komunikację, a nie na doskonałość językową, nawet w przypadku matury na poziomie rozszerzonym. Stało się to przyczynkiem do pojawienia się na I stopniu studiów neofilologicznych osób niedysponujących odpowiednimi umiejętnościami do rozumienia treści zajęć $w$ języku niemieckim i ostatecznie niemogących lub z trudem radzących sobie w toku studiów z osiągnięciem poziomu językowego C2 według ESOKJ po ukończeniu studiów magisterskich.

Wszystkie te czynniki miały wpływ na zmianę sposobu postrzegania celów kształcenia w ramach studiów I i II stopnia wśród gremiów Wydziału Filologicznego UŁ decydujących o kształcie programów studiów dla kolejnych pokoleń germanistów. Otwarto bowiem możliwość dosyć swobodnego decydowania o nachyleniu własnej ścieżki kształcenia w ramach tzw. specjalności, czyli pakietu zajęć niezależnych od specjalizacji będącej dziedziną, z zakresu której magistrant pisze pracę. Wprowadzenie specjalności umożliwiło oddzielenie zajęć, które stanowią podstawę kompetencji każdego neofilologa i są nieodzownym szkieletem programu kształcenia, od zajęć poszerzających perspektywę poznawczą studentów i pozwalających jednocześnie na elastyczne dopasowywanie treści do aktualnych potrzeb edukacyjnych. Jednak ze względu na niski poziom językowy abiturientów, którego przyczyny zostały wyjaśnione pokrótce powyżej, wybór specjalności, będących uzupełnieniem kształcenia podstawowego, możliwy jest dopiero na drugim stopniu, na studiach magisterskich.

Specjalizacje, w przeciwieństwie do specjalności, opierają się na tradycyjnej dychotomii, czyli na podziale na literaturoznawstwo (w postaci kanonicznej lub z elemenatmi kultury krajów niemieckiego obszaru językowego) i językoznawstwo (analogicznie ew. z elementami glottodydaktyki lub translatoryki). Specjalności za to są skomponowane tematycznie i mogą być z czasem zastępowane nowocześniejszymi rozwiązaniami, które podyktowane będą sytuacją na rynku pracy. Przykładowo dla rekrutacji w roku akademickim 2017/18 przewidziano następujący podział tematyczny specjalności: lingwistyka dla biznesu, tłumaczenia i przekład, specjalność nauczycielska oraz specjalność filologia germańska z drugim językiem obcym² ${ }^{2}$.

${ }^{1}$ Centralna Komisja Egzaminacyjna - instytucja mająca na celu przygotowywanie i organizowanie zewnętrznego systemu oceniania (egzamin gimnazjalny, egzamin maturalny oraz egzamin zawodowy), we współpracy z ośmioma Okręgowymi Komisjami Egzaminacyjnymi. Jej główne zadania określa ustawa o systemie oświaty (wg informacji znalezionych na stronie: https://cke.gov.pl [dostęp: 06.11.2018]).

${ }^{2}$ Zgodnie z oficjalnymi dokumentami dostępnymi na stronie www. germanistyka.uni.lodz. pl. Szczegółowy podział najlepiej obrazuje siatka godzin: http://germanistyka.uni.lodz.pl/germ/ wp-content/uploads/2017/09/siatki-FG-II-stopnia-2017-2018.xls) [dostęp: 02.03.2018]. 
W kręgu naszych zainteresowań dla dalszych rozważań w ramach niniejszej publikacji pozostaje specjalność lingwistyka dla biznesu, dla której dobór przedmiotów w latach poprzednich oraz aktualnie przedstawia się w sposób następujący:

\begin{tabular}{|c|c|c|c|c|c|c|c|c|c|c|}
\hline \multirow{2}{*}{ Semestr } & \multirow{2}{*}{$\begin{array}{l}\text { Specjalność: } \\
\text { lingwistyka } \\
\text { dla biznesu }\end{array}$} & \multirow[b]{2}{*}{ KOD } & \multicolumn{6}{|c|}{ Szczegóły przedmiotu } & \multirow{2}{*}{$\begin{array}{c}\text { Forma } \\
\text { zaliczenia } \\
\text { (oc./e) }\end{array}$} & \multirow[b]{2}{*}{ ECTS } \\
\hline & & & ck1 & w2 & p1 & war & $\begin{array}{l}\text { pr. } \\
\text { zaw. }\end{array}$ & razem & & \\
\hline 2 & $\begin{array}{l}\text { język specjalistyczny } \\
\text { (FINANSE) }\end{array}$ & & 28 & & & & & 28 & oc. & 2 \\
\hline 2 & $\begin{array}{l}\text { język specjalistyczny } \\
\text { (IT) }\end{array}$ & & & & & 28 & & 28 & oc. & 3 \\
\hline 2 & $\begin{array}{l}\text { język niemiecki } \\
\text { w środowisku } \\
\text { biznesowym }\end{array}$ & & 28 & & & & & 28 & oc. & 2 \\
\hline 2 & $\begin{array}{l}\text { tłumaczenia } \\
\text { pisemne biznesowe } \\
\text { i prawnicze } 1\end{array}$ & & & & 28 & & & 28 & oc. & 3 \\
\hline 2 & $\begin{array}{l}\text { zarządzanie } \\
\text { w odpowiedzialnym } \\
\text { biznesie (PL) }\end{array}$ & & & 28 & & & & 28 & e & 3 \\
\hline 3,4 & tekst i dyskurs (PL) & & & & 28 & & & 28 & oc. & 3 \\
\hline 3 & $\begin{array}{l}\text { język specjalistyczny } \\
\text { (BIZNES/CSR) }\end{array}$ & & 28 & & & & & 28 & oc. & 2 \\
\hline 3,4 & $\begin{array}{l}\text { zarządzanie } \\
\text { terminologią (PL) }\end{array}$ & & & & 28 & & & 28 & oc. & 3 \\
\hline 3 & $\begin{array}{l}\text { tłumaczenia } \\
\text { pisemne biznesowe } \\
\text { i prawnicze } 2\end{array}$ & & & & & 28 & & 28 & oc. & 3 \\
\hline 3,4 & $\begin{array}{l}\text { kompetencja } \\
\text { komunikacyjna } \\
\text { w życiu zawodowym }\end{array}$ & & 28 & & & & & 28 & oc. & 2 \\
\hline 4 & $\begin{array}{l}\text { tłumaczenia ustne } \\
\text { w negocjacjach } 1\end{array}$ & & & & & 28 & & 28 & oc. & 3 \\
\hline 3,4 & $\begin{array}{l}\text { praca projektowa } \\
\text { (tłumaczeniowa/ } \\
\text { biznesowa) (PL) }\end{array}$ & & & & & 28 & & 28 & oc. & 3 \\
\hline 3,4 & Praktyki zawodowe & & & & & & 30 & $\mathbf{0}$ & oc. & 1 \\
\hline & & & & & & & & 336 & & 33 \\
\hline
\end{tabular}

Tabela 1. Siatka godzin dla specjalności „lingwistyka dla biznesu”. Źródło: http:// germanistyka.uni.lodz.pl/germ/wp-content/uploads/2017/09/siatki-FG-II-stopnia-2017-2018.xls [dostęp: 2.03.2018] 
Już pobieżna analiza siatki pozwala na rozróżnienie zajęć wprowadzających terminologię fachową z dziedzin szeroko pojętego biznesu (język specjalistyczny: finasów, IT lub CSR) i zajęć pozwalających na zdobycie podstaw teoretycznych do pracy z tekstem i terminologią. Zajęcia zatytułowane „praca projektowa”, będące przedmiotem niniejszych rozważań, stanowią zatem zwieńczenie tego procesu dydaktycznego i mają umożliwić aplikację podstaw teoretycznych zdobytych na tychże zajęciach. Odwołują się również bezpośrednio do terminologii, z jaką studenci zetknęli się na zajęciach typu „język specjalistyczny” lub „”język niemiecki w środowisku biznesowym”.

\section{Założenia wstępne}

Przyjmując model zajęć, w czasie których główny punkt ciężkości musi być położony na procesy walidacyjne, czyli zakładający prowadzenie działań dokumentujących i sprawdzających poprawność dotychczasowych procesów kształcenia i dochodzenia do założonych poziomów kompetencyjnych ${ }^{3}$, należało podzielić działania projektowe na te o charakterze dotyczącym pracy $\mathrm{z}$ terminologią per se i te badające otoczenie biznesowe w kontekście prowadzonych badań i dydaktyki języków specjalistycznych. Stąd też wynika rozróżnienie widoczne w podtytule nazwy zajęć w przedstawionej powyżej tabeli z siatką godzin.

Każdy z typów projektów oprócz celu nadrzędnego, czyli integracji nabytych kompetencji z zakresu danej specjalności, zakłada również cele poboczne. W przypadku projektów tłumaczeniowych ma on uzmysłowić przyszłym absolwentom, a w pierwszej mierze - przyszłym pracownikom sektora biznesowego, zalety dobrych praktyk porządkujących i sortujących, a następnie prezentujących terminologię danej dziedziny. W przypadku projektów badających otoczenie biznesowe celem pobocznym jest uświadomienie konieczności elastycznego i kreatywnego operowania posiadanymi kompetencjami (m.in. z zakresu zarządzania, tłumaczeń negocjacyjnych lub ogólnie komunikacji), nabytymi w trakcie studiów.

Istotny z punktu widzenia rozwoju kompetencji społecznych jest również sposób realizacji projektów od strony socjalnej. Zarówno w przypadku pierwszego, jak i drugiego podtypu projektów studenci są zobligowani do

\footnotetext{
${ }^{3}$ Celowo używam dla określenia tego procesu pojęcia WALIDACJI, wskazując na potrzebę dokumentacji, nieobecnej w zjawisku ewaluacji. Zapożyczając ten termin z nauk ścisłych i technicznych, mam świadomość kontrowersji, do jakich może taki krok się przyczynić, czynię to jednak z rozmysłem, różnicując ponadto ewaluację jako proces wymagający większej systematyczności próbkowania. W przypadku opisywanych zajęć mówimy o sprawdzaniu opartym na kanonie dokumentującym kolejne kroki pracy i będącym jednorazowym epizodem następującym po około 3 semestrach kształcenia.
} 
pracy w minigrupach liczących od 2 do 4 osób. Wymóg ten podyktowany jest sytuacją panującą obecnie powszechnie na rynku pracy, kiedy to dany pracownik jest angażowany w działania wymagające intensywnej współpracy z innymi zatrudnionymi i musi pertraktować swoją pozycję, zakres działania wewnątrz zespołu oraz przejmować role konieczne w dzisiejszej rzeczywistości biznesowej (lider, ekspert, pracownik procesowy).

Zajęcia obejmują 28 godzin spotkań z wykładowcą. Jednak czas spędzony w sposób klasycznie akademicki, kiedy to wykładowca frontalnie steruje pracą studentów, oscyluje jedynie wokół 4 do 6 godzin. W takiej formie odbywają się zazwyczaj tylko pierwsze i ostatnie zajęcia. Pozostałe spotkania polegają na konsultacjach z poszczególnymi zespołami lub spotkaniach warsztatowych, podczas których uczestnicy rozwiązują zadania problemowe, typowe dla danej fazy projektu. Na spotkaniu początkowym określany jest terminarz wykonania i oddania poszczególnych etapów projektów, studenci tworzą grupy i definiują obszary swoich zainteresowań projektowych. Ostatnie spotkanie przewidziane jest natomiast na prezentację wykonanej pracy i omówienie wyników na forum całej grupy. Prowadzący dokonuje na nich również oceny oraz poddaje projekt pod dyskusję. Zajęcia typu warsztatowego mają na celu uwrażliwienie zespołów na trudne momenty pracy i ewentualne pułapki, które mogą być czasochłonne.

\section{Fazy projektu a walidacja nabytych kompetencji}

Już na wstępie niniejszego opisu należy podkreślić, że zdecydowana większość projektów przeprowadzonych i oddanych w latach akademickich 2016/17 i 2017/18 polegała na pracy tłumaczeniowej. Ich stosunek względem projektów biznesowych wynosił 12:3. Dysproporcja ta wynika w głównej mierze z mniejszego uzależnienia terminowego od podmiotów zewnętrznych, z którymi współpraca była wymagana przy projektach typu biznesowego, jak również z obaw o jakość otrzymywanego od tych podmiotów materiału ankietowego, stanowiącego podstawę badania. Nie bez znaczenia dla studentów wybierających kierunek tłumaczeniowy był też brak umiejętności pracy z narzędziami statystycznymi, koniecznymi do przedstawienia wyników końcowych w opracowaniach ankiet.

Mimo dopasowania rytmu pracy do możliwości poszczególnych zespołów, każdy z nich musiał wykazać się terminowym oddaniem części projektu i przejść tym samym przez przewidziane harmonogramem pracy kroki. Poniżej zaprezentuję zatem fazy projektów osobno dla kierunku tłumaczeniowego oraz biznesowego i omówię pokrótce, w jaki sposób następowała walidacja kompetencji nabytych na wcześniejszych etapach nauki w ramach specjalności lingwistyka dla biznesu. 


\subsection{Projekty tłumaczeniowe}

Po przedstawieniu na pierwszych zajęciach terminarza oraz spektrum możliwych działań projektowych studenci prezentują na najbliższym spotkaniu:

- temat i rodzaj projektu - jest to pierwsze sprawdzenie się minigrup jako zespołów i weryfikacja umiejętności negocjacyjnych ich członków. Zazwyczaj wyłania się już w tej fazie naturalny lider bądź liderzy. Na tym etapie nie mamy jeszcze do czynienia z rzeczywistym sprawdzeniem umiejętności translatorycznych lub językowych, tylko z pewnego rodzaju wysondowaniem i znalezieniem tematu odpowiadającego ambicjom i z drugiej strony możliwościom czasowym członków zespołu i wyobrażeniom o własnych kompetencjach. Skutkiem tego zdarza się, że zespoły, w których znajdują się osoby posiadające wysokie umiejętności, ale niebędące liderami, wybierają tematy mało ambitne i odtwórcze. Zadaniem prowadzącego zajęcia jest w takim przypadku wskazanie rozwinięcia zaproponowanego tematu i możliwości aplikacji projektu w rzeczywistej pracy.

Najczęstsze propozycje studenckie oscylują wokół tworzenia glosariusza. Symptomatyczne jest jednak, że pojęcie glosariusza rozumiane jest przy tym dosyć jednostronnie. Najczęściej bowiem jako cel jego stworzenia studenci podają, jak najbardziej prawidłowo z punktu widzenia pracy tłumacza korzystającego z translation memories $\mathrm{w}$ ramach CAT czy też w zespołach tłumaczeniowych, konieczność zestawienia terminologii danej poddziedziny, co ma pozwolić na zwiększenie precyzji tłumaczenia i przekłada się na wzrost jakości usługi. Rzadko kiedy uświadamiają sobie jednak, że glosariusz może być również, w takim samym stopniu jak w świecie tłumaczeniowym, podstawą pracy w świecie korporacyjnym. Nie będzie on wtedy stanowił takiej samej wartości dla każdego pracownika, lecz stanie się narzędziem wprowadzającym dla nowo zatrudnionych członków zespołu, którzy nie zetknęli się z daną dziedziną w ogóle lub w stopniu wystarczającym do samodzielnego wykorzystywania danej terminologii. Glosariusz taki musi jednak spełniać inne założenia wstępne niż glosariusz do celów tłumaczeniowych i oprócz funkcji łączącej terminy w dwóch lub więcej językach będzie on nierzadko uzupełniony o funkcję instruującą lub wyjaśniającą dany termin.

- zebranie materiałów lub akquiza - po wybraniu tematu minigrupy zabierają się do zbierania materiału stanowiącego korpus do dalszej pracy ekscerpcyjnej. Niektóre z grup, przy wsparciu prowadzącego oraz przedstawiciela dziekana do współpracy z otoczeniem biznesowym, 
kontaktują się z firmami współpracującymi z Wydziałem Filologicznym UŁ i poszukują obszarów, w których glosariusz stałby się przydatnym narzędziem dla osób nowo zatrudnionych lub zmieniających dział. Na korpusy dla glosariuszy pierwszego typu składa się od kilku do kilkunastu tekstów w języku wyjściowym oraz odpowiednio tyle samo tekstów równoległych w języku lub językach (w niektórych przypadkach projekty obejmowały też język angielski) docelowych. W przypadku glosariuszy do użytku biznesowego grupy muszą przeprowadzić wywiad i określić: grupę docelową, obszar roboczy oraz zakres integracji terminologii w odniesieniu do zakresu działań dla danego stanowiska. Na koniec opisywanej fazy grupy zajmujące się tworzeniem glosariuszy z terminologii korpusowej przedstawiają zebrany materiał terminologiczny w języku wyjściowym na konsultacjach. Grupy tworzące rozwiązania dla biznesu przedstawiają zebrany materiał temrinologiczny i odnoszą go do kontekstu pracy na danym stanowisku. Ze względów praktycznych glosariusze wykonywane są w programie Excel. Zapewnia to minimalizację kosztów i wysoką dostępność narzędzia w każdych warunkach biurowych.

- zrozumienie terminologii i szukanie ekwiwalencji - w nastepnym kro$\mathrm{ku}$, po zebraniu materiału będącego podstawą dalszej pracy, studenci przechodzą do pracy nad aspektem semantycznym terminologii. Podstawowym warunkiem sukcesu w doborze właściwego odpowiednika w języku/jezykach docelowych, niezależnie od typu przygotowywanego glosariusza, jest bowiem właściwe zrozumienie określonego terminu w kontekście danej dyscypliny, w ramach której się poruszają. Znajdywanie ekwiwalencji staje się dzięki temu dużo łatwiejsze i obarczone mniejszym ryzykiem błędu. Na konsultacjach przewidzianych w tym kroku przygotowywane są listy z wyróżnieniem poszczególnych typów ekwiwalencji. Wspólnie z prowadzącym studenci zastanawiają się nad konsekwencjami wyboru danego typu ekwiwalencji.

- sprawdzenie poprawności i funkcjonalności, wnioski i prezentacja - glosariusze poddawane są kontroli przez prowadzącego pod kątem poprawności formalnej i semantycznej. Zgłoszone błędy muszą być poprawione przez studentów we własnym zakresie. W przypadku glosariuszy skierowanych do wykorzystania w biznesie projekty są następnie wysyłane do partnerów. Minigrupy kontaktują się po kilku-, kilkunastu dniach z przedstawicielami firm i zbierają informacje zwrotne dotyczące funkcjonalności glosariuszy, które następnie uwzględniane są we wprowadzanych poprawkach. W przypadku niektórych glosariuszy tego typu użytkownicy otrzymują dodatkowo zestaw ćwiczeń 
językowych i tekstów wprowadzających do terminologii, ułatwiający pracę z przekazanym glosariuszem.

W ostatniej fazie projektu minigrupy przedstawiają poszczególne kroki wykonania projektu na plenum podczas ostatnich zajęć w semestrze, omawiają wspólnie wnioski, jakie mogli wyciągnąć z aplikacji swojej wiedzy w praktyce, i wskazują problemy, które napotkali podczas pracy.

\section{Przykłady glosariuszy}

Glosariusz dla działu Travel and Expences w CERI International Sp. z o.o. został wykonany przez dwoje studentów, panią Paulinę Kucińską i pana Andrzeja Kuczkowskiego w semestrze zimowym roku akademickiego 2017/18. Glosariusz skierowano do nowo rekrutowanych pracowników działu i został on uzupełniony o dodatkowe ćwiczenia i polskojęzyczny słownik podstawowych terminów zawartych w glosariuszu. Opracowany materiał odnosi się do pojęć widocznych w programie do wykonywania rozliczeń podróży opartym na systemie SAP i ma pomagać w mailowej komunikacji niemiecko-, polsko- i anglojęzycznej między pracownikami działu a pracownikami, których podróże są rozliczane. Glosariusz ten jest bardzo ciekawym przykładem pracy, która po wdrożeniu polepszyła jakość komunikacji w zespole i przyczyniła się do stworzenia nakładki systemowej w języku polskim. Okazało się bowiem, że nawet dla pracowników działu z dłuższym stażem typowe było mieszanie kodów w komunikacji mailowej, co powodowało obniżenie standardów jakościowych.

Zupełnie inne cele przyświecały za to twórczyniom glosariusza terminologii położniczej, stworzonego w roku akademickim 2016/17 przez panie: Martę Grzegory i Martę Andrzejewską. Zarówno wybór tematyki glosariusza, jak i zapewnienie materiału wejściowego w postaci dokumentów koniecznych do wypełnienia przed porodem w polskich szpitalach, kierowane były przypadkami, z jakimi zetknęła się pani Grzegory w trakcie swoich praktyk studenckich. Została poproszona przez bliską osobę z rodziny, pracującą w szpitalu jako położna, o pomoc w tłumaczeniu dokumentów dla osoby niemieckojęzycznej, przebywającej aktualnie na oddziale szpitalnym. Doświadczenie to zostało potem powtórzone z inną niemieckojęzyczną pacjentką i stało się przyczynkiem do wyboru takiego właśnie tematu projektowego. Celem glosariusza stało się zatem nie stworzenie materiału dla pracowników, służącego do kontaktu na płaszczyźnie specjalista-specjalista, lecz umożliwienie sprawnej komunikacji z pacjentem w momencie, kiedy zapewnienie obecności tłumacza jest czasowo niewykonalne. Dlatego też w glosariuszu znalazły się gotowe frazy i syntagmy. 
KRZYSZTOF SAKOWSKI

\begin{tabular}{|c|c|c|}
\hline originale Phrase & Übersetzung ins Englische & Übersetzung ins Polnische \\
\hline Bearbeitung und Abrechnung & processing and calculation & procesowanie i rozliczanie \\
\hline über das Reisekosten-Portal abrechnen & to calculate via Travel Expense Portal & rozliczać na portalu dla podróży służbowych \\
\hline $\begin{array}{l}\text { Reisekostenabrechnung bearbeiten und } \\
\text { berichtigen }\end{array}$ & to process and correct travel expense claim & opracować i skorygować rozliczenie kosztów podróży \\
\hline \begin{tabular}{|c|}
$\begin{array}{c}\text { Reisekostenabrechnung wegen der nicht völlig } \\
\text { stimmenden mit Reiserichtlinien Angaben } \\
\text { nicht bearbeiten }\end{array}$ \\
\end{tabular} & \begin{tabular}{|} 
to not process travel expense claim due to \\
inaccurate information according to travel rules
\end{tabular} & $\begin{array}{c}\text { nie opracować rozliczenia kosztów podróży z powodu } \\
\text { danych nie w pełni zgadzających się się z przepisami } \\
\text { dotyczącymi podróży }\end{array}$ \\
\hline $\begin{array}{c}\begin{array}{c}\text { Abrechnung kann nicht volständig bearbeitet } \\
\text { werden }\end{array} \\
\end{array}$ & the calculation cannot be processed completely & rozliczenie nie może być w pełni opracowane \\
\hline Reise zur Auszahlung sperren & to block travel payment & zablokować opłacenie podróży \\
\hline \begin{tabular}{|c|} 
Reise wegen der falschen/fehlenden \\
Firmierung auf der \\
Hotelrechnung/Mietwagenrechnung sperren
\end{tabular} & $\begin{array}{l}\text { to block travel due to false/missing company } \\
\text { name on the tax bill/bill of rental car }\end{array}$ & $\begin{array}{c}\text { zablokować podróż z powodu błędnej/brakującej } \\
\text { nazwy firmy na rachunku hotelowym lub rachunku za } \\
\text { wynajem auta }\end{array}$ \\
\hline gesperrte Reise neu bearbeiten & to process a blocked travel once again & opracować na nowo wstrzymaną podróż \\
\hline zur Auszahlung freischalten & to release for payment & odblokować do wypłaty/zwolnić do płatności \\
\hline in dem nächstmöglichen Termin auszahlen & to pay off as soon as possible & wypłacić w najbliższym możliwym terminie \\
\hline Rückzahlung leisten & to make a repayment & dokonywać spłaty \\
\hline um Beachtung der Hinweise bitten & to ask for compliance with hints & prosić o uwzględnienie wskazówek \\
\hline bei der nächsten Reisekostenabrechnung & during closest travel expense claim & przy następnym rozliczeniu kosztów podróży \\
\hline Option ankreuzen & to mark the option & zaznaczyć opcję \\
\hline Unterkunftsoption im System löschen & $\begin{array}{l}\text { to delete the accomodation option in the } \\
\text { system }\end{array}$ & odznaczyć/usunąć opcję n \\
\hline Haken im System herausnehmen & to remove a tick in the system & odznaczyć krzyżyk (przy danej opcji) w systemie \\
\hline $\begin{array}{c}\text { Quoten für ... stimmen mit der Rechnung nicht } \\
\text { überein }\end{array}$ & the amounts of ... do not match with the invoice & kwoty za ... nie zgadzają się z rachunkiem \\
\hline $\begin{array}{l}\text { eingetragene Angaben erlangen eine } \\
\text { Korrektur }\end{array}$ & the entered information needed the correction & podane informacje wymagały korekty \\
\hline $\begin{array}{l}\text { durch die Korrektur(en) entstandene } \\
\text { Rückforderungen saldieren }\end{array}$ & to balance reclaims caused by corr & $\begin{array}{c}\text { saldować ząadania zwrotu (kwot) powstałe w wyniku } \\
\text { korekt }\end{array}$ \\
\hline $\begin{array}{c}\text { den Rückforderungsbetrag mit künftigen } \\
\text { Reiseabrechnungen saldieren }\end{array}$ & $\begin{array}{l}\text { to balance a reclamation amount with future } \\
\text { travel expenses }\end{array}$ & $\begin{array}{l}\text { wyrównać sumę zwrotów przyszłymi wydatkami } \\
\text { związanymi z podróżami }\end{array}$ \\
\hline Saldo vollständig ausgleichen & to clear the balance & całkowicie wyrównać saldo \\
\hline
\end{tabular}

Tabela 2. Fragment glosariusza dla działu Travel and Expences w CERI International Sp. z o.o. Źródło: opracowanie własne

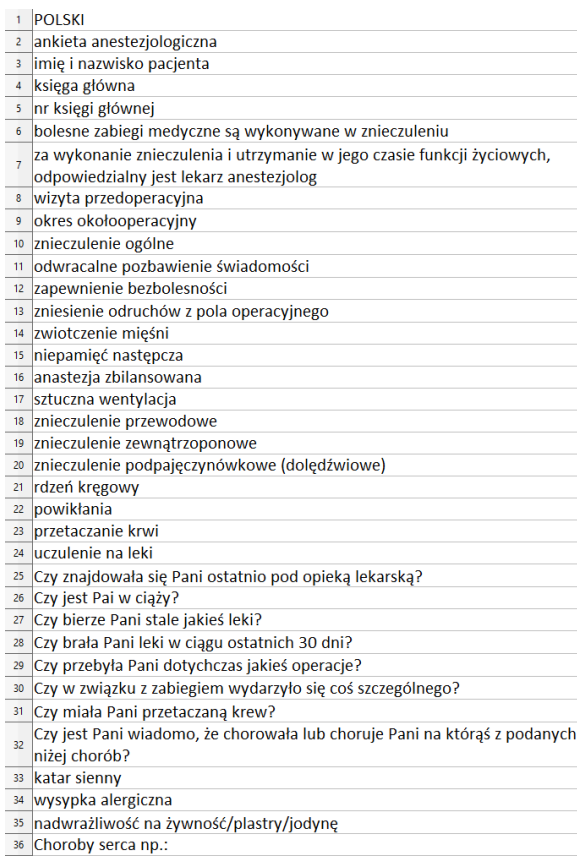

Tabela 3. Fragment glosariusza terminologii położniczej. Źródło: opracowanie własne 
Z informacji udzielonych przez panią Grzegory po oddaniu i zaliczeniu projektu wynika, że glosariusz stał się podstawą do wdrożenia minirozmówek w językach niemieckim i angielskim w jednym z łódzkich szpitali.

\subsection{Projekty biznesowe}

W przypadku projektów biznesowych mamy do czynienia z zupełnie inną metodologią i rozmieszczeniem akcentów weryfikujących nabyte umiejętności, wiedzę i kompetencje społeczne. Projekty te skupiają się na badaniu kompetencji językowych we współpracujących z Wydziałem Filologicznym firmach w obrębie języków specjalistycznych w odniesieniu do ogólnego poziomu językowego, jakim pracownicy firm dysponują. Ujawnia się przy tym szereg cennych aspektów i korelacji tworzących obraz kształcenia i wykorzystania zawodowego języków obcych na rynku polskim. Analiza wyników przeprowadzonych badań pozwala na wyciągnięcie wniosków będących podstawą do dalszych kroków, zarówno dydaktyczno-naukowych, leżących w dalszej kompetencji m.in. IFG UŁ, jak i projektowych, kiedy to projekty biznesowe stają się podwaliną projektów translatorskich dla kolejnych grup studenckich w następnym roku akademickim. Poszczególne kroki pracy zespołów studenckich dla projektów biznesowych przedstawiam analogicznie poniżej.

6. Wybór zakresu badania i grupy zawodowej - kluczowym w tym przypadku jest wybór podmiotu zewnętrznego, z którym dana minigrupa chce współpracować. Ze względu na ożywione kontakty Wydziału Filologicznego z łódzkim otoczeniem gospodarczym, które są pielęgnowane przez koordynatora ds. współpracy z biznesem, istnieje duża łatwość nawiązywania współpracy w zakresie takich projektów. Niejednokrotnie porozumienie między instytucjami jest również zawierane z inicjatywy studentów będących jednocześnie pracownikami danych firm. Po wyborze partnera biznesowego studenci są zobowiązani do zapoznania się z jego portfolio i zastanowienia się, jakie działy posługują się jakim językiem specjalistycznym, jak wygląda konstelacja komunikacy na tych działów, jaki profil językowy jest pożądany u osób zatrudnianych w tych działach, jakie problemy językowe mogą napotkać pracownicy określonych działów. Posiadając podstawowe założenia badawcze wynikające z tychże przemyśleń, zespół studencki kontaktuje się z podmiotem zewnętrznym.

7. Nawiązanie współpracy z podmiotem zewnętrznym - podczas pierwszych kontaktów z wybraną firmą ustalane są zarówno szczegóły formalne, jak i zakres badania oraz późniejszego wykorzystania danych. 
W większości przypadków konieczne jest podpisanie stosownych umów i klauzul dotyczących bezpieczeństwa i poufności. Następnie grupy są zobowiązane do nawiązania kontaktu $\mathrm{z}$ badanym działem i na podstawie krótkiej rozmowy z pracownikami określenia, czy poczynione wstępnie założenia badawcze są zgodne z rzeczywistością, czy też wymagają dalszej weryfikacji i konsultacji z prowadzącym zajęcia.

8. Stworzenie ankiety i przeprowadzenie badania - na podstawie zweryfikowanych danych tworzona jest pierwsza wersja ankiety, która podlega konsultacji z prowadzącym zajęcia oraz z pracownikiem działu HR danej firmy. Po akceptacji ustalany jest termin przeprowadzenia badania i ilość osób, które zostaną temu badaniu poddane. Podczas przeprowadzania badania obecny być musi przedstawiciel grupy studenckiej i pracownik działu HR.

9. Analiza wyników - następnie nadchodzi najbardziej żmudna część pracy, czyli analiza statystyczna. Mimo zachęt ze strony prowadzącego żadna z grup nie zdecydowała się na użycie darmowego narzędzia do sporządzania statystyk (R-statistics). Jedna grupa opierała się na programie Excel, a dwie - na własnych obliczeniach, co znacznie wydłużyło pracę i naraziło badanie na ryzyko błędów. Było to tym samym wyzwanie dla prowadzącego przy weryfikacji danych. Stanowi to również koronny dowód na braki w umiejętności korzystania ze współczesnych narzędzi statystyczno-matematycznych wśród absolwentów germanistyki UŁ. Uwagę na ten problem zwracali też przedstawiciele INFOSYS Polska oraz CERI International Sp. z o.o. podczas spotkań rady biznesu, dla których umiejętności te stanowią podstawę do dalszego wdrożenia do pracy zawodowej.

10. Prezentacja i wnioski - na koniec, podobnie jak w przypadku projektów tłumaczeniowych, grupa przygotowuje i przeprowadza prezentację, w której zawarte są informacje o celu i sposobie przeprowadzonego badania, statystki udzielonych odpowiedzi oraz wnioski. W wyniku wszystkich przeprowadzonych dotychczas badań ankietowych ewidentna jest potrzeba dodatkowego wsparcia w postaci szkoleń, warsztatów lub prezentacji dla akwizycji słownictwa specjalistycznego używanego w typowych dla danego stanowiska sytuacjach komunikacyjnych. Co ciekawe, u osób z większym stażem na danym stanowisku można odnotować potrzebę dalszej nauki ogólnej i specjalistycznej danego języka obcego, co wskazywałoby na chęć wyjścia poza schematyczny obszar komunikacji i potrzebę swobodnego porozumiewania się z osobami niemieckojęzycznymi (w tym przypadku). 


\section{Feedback ze strony otoczenia biznesowego}

Zarówno w przypadku projektów tłumaczeniowych, jak i biznesowych mieliśmy do czynienia w dwóch poprzednich latach z licznymi aplikacjami wypracowanych glosariuszy lub z wykorzystaniem danych pochodzących z ankiet $w$ firmach, z którymi Wydział Filologiczny UŁ oraz IFG współpracują. Jest to niezwykle istotny element całego założenia zajęć projektowych, wskazuje on bowiem na bezpośrednie zastosowanie wypracowanych umiejętności, wiedzy i kompetencji społecznych w realnym, współczesnym otoczeniu gospodarczym. Z pewnością przedmiot ten stanowi realny pomost między teoretycznymi zajęciami, nawet o zabarwieniu praktycznym, a późniejszą pracą zawodową.

Należy odnotować również, że informacje zwrotne od naszych partnerów biznesowych służą nie tylko bezpośrednio studentom do poprawy własnych prac, ale również prowadzącemu do zrewidowania założeń ogólnych. I tak chociażby, po pierwszej edycji przedmiotu, zdecydowałem się na kilka zmian formalnych oraz zwróciłem uwagę na pewne aspekty, które wcześniej uznawałem za nieistotne. Po pierwsze, pracodawcy zwracali uwagę na możliwości grupowania słownictwa na różnych arkuszach programu Excel, tak aby dany arkusz był dostosowany do pracy na jednym stanowisku. Po drugie, pomocne wydaje się wykorzystanie pól powiązanych do uwidaczniania, np. fraz synonimicznych. Jest to możliwe dzięki stosowaniu formuł odsyłających, tak aby w razie konieczności powtórzenia danego zwrotu, chociażby w korespondencji, skrócić czas wyszukiwania synonimu. Po trzecie, zawsze mile widziane są materiały uzupełniające, np. tutoriale, które mogą być wykorzystane bezpośrednio w zaprezentowanej formie lub wewnętrznie rozwijane do szkoleń czy prezentacji. Stanowią one niewątpliwą pomoc dla nowo przyjmowanych pracowników, często będących jeszcze studentami neofilologii i nieposiadających właściwej wiedzy specjalistycznej i doświadczenia z danej dziedziny.

\section{Podsumowanie}

W obecnych czasach dalece posunięta specjalizacja, również językowa, jest oczywistym wymogiem stawianym coraz liczniejszej grupie pracowników w tzw. zawodach nowoczesnych. Jednak ze względu na dynamikę rynku stawia ona przed pracownikiem potrzebę ustawicznego kształcenia, przekwalifikowania się, elastycznego dopasowania do nowych warunków zatrudnienia. Kształcenie filologiczne, będące w tym przypadku podstawą dla dalszej specjalizacji językowej, ma umożliwiać nie tylko zdobycie ogólnych kompetencji 
językowych na poziomie $\mathrm{C} 1+/ \mathrm{C} 2$, lecz również dać narzędzia do dalszego skutecznego kształcenia autonomicznego, korzystające ze zdobyczy lingwistyki stosowanej. Wskazując w ramach zajęć projektowych na autentyczne potrzeby otoczenia gospodarczego, jesteśmy w stanie wypracować podstawy dalszych dobrych praktyk w opracowywaniu słownictwa i w zrozumieniu potrzeb edukacyjnych, zarówno własnych, jak i zespołów pracowników. Dzięki takim doświadczeniom, zebranym jeszcze na etapie studiów, absolwenci powinni lepiej odnaleźć się w ciągle zmieniającej się rzeczywistości zawodowej i móc łatwiej dzięki temu odnieść w przyszłości sukces.

\section{Bibliografia}

- Bednarek A. (2015), Zapotrzebowanie firm z sektora nowoczesnych usług biznesowych w zakresie kandydatów ze znajomościq języków obcych. Publikacja w ramach projektu "Lingwistyka dla ekoodpowiedzialnego biznesu MA", FSS/2014/HEI/W/0110, Uniwersytet Łódzki, Wydział Filologiczny, Łódź. Źródło: http://www.l4bma.uni.lodz.pl/ewaluacja [dostęp: 21.06.2018].

- Berdychowska Z. (2010), Rahmenbedingungen und Ziele fachkommunikativer Ausbildung im Germanistikstudium. W: Duś M., Zenderowska-Korpus G. (red.), Fachsprachenpropadeutik im Germanistikstudium, Częstochowa, s. 39-48.

- Ćwiąkalska M., Hojda P. Ostrowska-Zakrzewska M. (2009), Losy zawodowe absolwentow Uniwersytetu Jagiellońskiego, rocznik 2007/2008. Raport z badań, Kraków.

- Grucza S. (2008), Lingwistyka języków specjalistycznych, Warszawa.

- Lewicka G. (2015), Kreativität in der Hochschuldidaktik vom Standpunkt der konstruktivistischen Kognitionstheorien. W: Lewicka G., Lewicki R. (wyd.), „Perspektiven für Deutsch als Kontaktsprache in Europa 2. Sonderausgabe der Konińskie Studia Językowe”, nr 1 (4), 2016, s. 53-59.

- Lukszyn J. (2008), Tekst specjalistyczny pod lingwistycznq lupq. W: Lukszyn J. (red.), Podstawy technolingwistyki I, Warszawa, s. 155-172.

- Weber S. (2010), Fachsprachenpropädeutik im Germanistikstudium: Ziele, Merkmale, Inhaltskomponenten. W: Duś M., Zendrowska-Korpus G. (red.), Częstochowa, s. 9-38.

- Weigt Z. (2010), Podiumsdiskussion: Welchen Referenzrahmen braucht die germanistische Translationsdidaktik?. W: Bartoszewicz I., Dalmas M., Szczęk J., Tworek A. (red.), Germanistische Linguistik extra muros - Aufforderungen, Linguistische Treffen in Wroclaw vol. 5: Beihefte zum ORBIS LINGUARUM, Wrocław, Dresden, s. 218-220, 224, 230-231. 


\section{Summary}

In this paper, the author attempts to describe and originate classes: project offered in the field of Linguistics for Business as part of second-cycle studies in german studies at the Faculty of Philology of the University of Lodz. The aim of these classes is a practical and conscious application and checking of the knowledge, skills and social competences acquired during the master's studies. The project activities go beyond the purely theoretical area, showing participants the current needs of the business environment thanks to the cooperation with numerous external entities.

Keywords: linguistics for bussines, applied linguistics, glossary 